\title{
Modelling the variation of suction pressure during caisson installation in sand using FLAC3D
}

\begin{abstract}
1 A suction caisson is an upturned 'bucket' of cylindrical shape made from steel. This

2 type of foundation has been very popular in the oil and gas industry and the current

3 trend is to extend its use to offshore wind farms. Seepage conditions play a pivotal role

4 in suction caisson installation process in sand. Pressure gradients generated by imposed

5 suction inside the caisson cavity cause an overall reduction in the soil resistance around

6 the caisson wall and tip. This transient soil loosening around the caisson wall helps

7 caisson penetration into the seabed. In this paper, we present a study of the role of

8 seepage on the suction caisson installation process in homogenous sand. We also

9 investigate the effects of seepage conditions on soil resistance to caisson penetration

10 with a particular focus on how frictional and tip resistance are differently affected. For

11 this purpose, a series of numerical models are developed using FLAC3D. These models

12 are used to investigate the variation of suction pressure during caisson installation in

13 homogenous sand and to predict the amount of suction required to penetrate the caisson

14 to a certain depth. An explicit strategy is used for each embedment depth, which

15 consists of updating current suction based on displacement history available after the
\end{abstract}


1 previous prescribed displacement increment. The numerical models are developed for

2 different caisson sizes and wall thicknesses to study the effects of caisson geometry on

3 soil resistance during caisson installation. Problem dimensions are normalised with

4 respect to the diameter of the caisson in order to obtain the results that can be applied to

5 any caisson size. The results showed that suction pressure tends to increase with the

6 embedment depth. Additionally, the overall behaviour and the pressure variation with

7 depth are similar for caissons of different size and wall thickness. Finally, in order to

8 validate the developed numerical models, data from centrifuge tests are investigated and

9 compared with the results obtained from this study. The developed finite difference

10 models are found to be in good agreement with centrifuge tests, in particular for thicker

11 caissons $(\mathrm{t} / \mathrm{D}=1 \%)$.

\section{Keywords}

13 Suction caisson foundation; Installation in sand; Normalised problem; FLAC3D.

\section{1. Introduction}

15 Suction caisson foundation has proven to be efficient and versatile as a support for

16 offshore structures and appears to be a very attractive option for future use in offshore

17 wind turbines (Hogervorst, 1980; Tjelta, 1994; Tjelta, 1995; Byrne et al., 2002; Byrne \&

18 Houlsby, 2003; Bransby \& Yun, 2009; Harireche et al., 2013; Ackmus, et al., 2013;

19 Ibsen, et al., 2014; Ibsen, et al., 2014). The initial penetration into the seabed takes place 
1 under the caisson self-weight. Once the rim of the caisson makes a sufficient seal with

2 the seabed due to its dead weight, suction is subsequently applied by pumping out the

3 water trapped inside the internal caisson cavity to push the caisson into the desired

4 depth. The simplicity of the installation procedure, in addition to economical advantages

5 of this type of foundation, has made it an attractive option for use in a variety of

6 applications such as mooring systems (Hogervorst, 1980; Senper \& Auvergne, 1982),

7 permanent offshore foundations for oil and gas platforms (Tjelta, 1995; Bye et al., 1995)

8 and recently, as a potential foundation for offshore wind turbines (Houlsby \& Byrne,

9 2000). For caisson installation in sand, seepage causes an overall reduction in soil

10 resistance and facilitates caisson penetration. Without soil loosening due to the induced

11 seepage it is often recognised that the downward force produced by suction couldn't

12 overcome soil resistance for installation in sand (Erbrich \& Tjelta, 1999; Senders \&

13 Randolph, 2009; Senper \& Auvergne, 1982; Tjelta et al., 1986; Tran et al., 2004; Tran et

14 al., 2005). Most design procedures of caisson installation in sand take into account the

15 role of pore water seepage induced by suction (Tjelta, 1994, 1995; Bye et al., 1995;

16 Houlsby \& Byrne, 2005). The role of suction during caisson installation in sand has also

17 been investigated using centrifuge model testing (Tran \& Randolph, 2008; Tran et al.,

18 2007), field installation trials (Tjelta, 1995; Lacasse, 1999). It should be noted that, field

19 tests have been conducted and reported less, because firstly they are not cost effective

20 trials compared with laboratory tests, and secondly field trials are more complex since 
1 there is not enough control of soil and loading conditions during the test. Nevertheless,

2 data obtained from field trials offer priceless means to validate laboratory results and

3 calibrate models. Generally speaking, centrifuge experiments are relatively expensive

4 and subject to various test restrictions. They can simulate the soil-foundation system

5 under repeatable and controlled conditions. To overcome the cost problem, some

6 installation studies have been carried out using different numerical methods and

7 validated against available field as well as centrifuge data (Zhang et al., 2004; Harireche

8 et al., 2013, 2014; Mehravar, et al., 2014). While the general principles of suction

9 installation in sand have been recognised, details of the required amount of suction

10 pressure at different stages of the installation process for various caisson geometries and

11 wall thicknesses have not been well studied using numerical methods.

12 This paper aims at investigating the effect of seepage on soil resistance during suction

13 caisson installation at different stages of penetration into the seabed by developing a

14 series of finite difference models using FLAC3D commercial software (Itasca, 2009). In

15 addition, the effect of caisson geometry and wall thickness on soil resistance, and hence

16 the required amount of suction pressure during the installation process are investigated.

17 The main aim of this study is to gain an insight on the installation mechanism of caisson

18 foundations in sand, for a better prediction of soil resistance, and subsequently suction

19 pressure during the installation process. The soil is considered as homogenous sand and

20 the suction required at different penetration stages is calculated and applied using an 
1 explicit method. The suction magnitude required at different embedment depths is

2 predicted and presented as a normalised quantity. Additionally, some data obtained from

3 centrifuge testing is used to confirm and validate the FLAC3D results.

\section{2. Suction caisson installation process}

5 The installation of caisson offshore foundations often relies on suction pressure to push

6 the caisson to the required penetration depth. This procedure combines caisson self

7 weight and pressure differential generated on the caisson lid to generate a downward

8 force that should overcome soil resistance to caisson penetration.

9 Compared to piles, caisson foundations offer the advantage of a simpler installation that

10 requires less equipment and takes generally a much shorter time. The installation of

11 caisson foundations can take place during weather conditions that may cause serious

12 disturbance to offshore pile driving (Cotter, 2006).

13 Normally, the caisson is constructed onshore and then moved to the offshore site.

14 Primarily, the valves at the top of the caisson lid are kept opened to allow any trapped

15 air inside the caisson cavity to escape, while a crane is used to lower the caisson into the

16 seabed. Initial penetration takes place under self-weight. At the initial penetration depth,

17 the seabed material above the caisson tip, surrounding the caisson wall, forms a natural

18 seal which is vital to the subsequent installation stage. Full penetration requires an

19 increasing downward pressure which is generated by suction. The water trapped inside 
1 the caisson cavity is pumped out, which imposes a pressure differential on the caisson

2 lid and results into a downward force. Water pumping is maintained until a desired

3 penetration depth is achieved, then pumping is stopped and all valves are closed (Cotter,

4 2006).

5 Whilst suction is beneficial to the installation of caisson foundations in sand, its

6 magnitude must be controlled to avoid the formation of piping channels. The piping

7 phenomenon may cause a deterioration of the seal formed by the soil around the caisson

8 wall, ultimately leading to a failure of the installation process (Ibsen \& Thilsted, 2010,

9 2011).

10 3. Normalised caisson geometry and boundary conditions

11 A series of three dimensional finite difference models are developed using FLAC3D

12 software which is a three-dimensional numerical program based on an explicit finite

13 difference method with a wide range of capabilities to solve complex problems in

14 mechanics, and particularly in geomechanics (Itasca, 2009). Taking advantage of the

15 symmetrical nature of the problem, only one-quarter of the whole problem is modelled

16 (Figure 1). A model problem of a suction caisson with radius $\mathrm{R}$, height $\mathrm{H}$ and

17 embedment depth $\mathrm{h}$ is considered. All dimensions are normalised with respect to the

18 diameter of the caisson. The coordinate axes for FLAC3D model are placed at the

19 central point of the soil plug trapped inside the caisson, and the $\mathrm{z}$-axis positioned along 
1 the caisson central axis pointing upward. The base of the model is fixed in $\mathrm{x}, \mathrm{y}$ and $\mathrm{z}$

2 directions, and also roller boundaries are imposed on the sides of the model (Figure 2).

3 Different caisson sizes were modelled and their details are provided in Table 1. It should

4 be mentioned that most of the aspect ratio which are embedment depth to caisson

5 diameter $\mathrm{h} / \mathrm{D}$ and wall thickness to diameter $\mathrm{t} / \mathrm{D}$ are similar to those considered in field

6 trials.

7

8

9

10

Table 1

Figure 1

Figure 2

\section{4. Soil characterization and model preparation}

12 The soil is considered as fully saturated sand and its behaviour is described using an

13 elasto-plastic Mohr-Coulomb constitutive model (Table 2). A linear-elastic material

14 model is used to define the material behaviour of the steel caisson. The skin friction 
1 resistance is modelled by placing an interface between the caisson wall and soil. For this

2 purpose, a friction angle of $20^{\circ}$ and a cohesion equal to zero are considered to define the

3 interface properties. Additionally, an interface is defined between the tip of the caisson

4 and soil. In order to install the interfaces, the grid representing the soil is created firstly

5 and interfaces are attached to the zone faces in contact with caisson walls and caisson

6 tip. An enlarged area around caisson wall is presented in Figure 3 to indicate the

7 interfaces by yellow lines and finite difference mesh.

$\underline{\text { Table } 2}$

$\underline{\text { Figure } 3}$

\section{5. Modelling the installation process}

10 Firstly the model is taken to equilibrium under gravity loading before applying suction.

11 Initial pore water pressure and stress distribution are obtained at this stage. In order to

12 draw conclusions that are not related to prototype dimensions, the following

13 dimensionless counterpart of the caisson penetration depth is adopted:

$$
\mathrm{h}^{*}=\mathrm{h} / \mathrm{D}
$$


1 At the next stage, suction is applied at the top of the soil plug using explicit method.

2 The explicit procedure is used to obtain the required suction as a function of the

3 penetration depth. This procedure consists of prescribing small increments of

4 displacement $\Delta \mathrm{h}$ to the caisson by applying a vertical small velocity at the caisson top

5 and then updating suction in an explicit way. In other words, increment $\Delta \mathrm{h}_{\mathrm{n}+1}$ is applied

6 in the presence of suction which is consistent with the total displacement up to

7 increment $\Delta \mathrm{h}_{\mathrm{n}}$. This procedure enables the investigation of caisson behaviour at

8 different embedment depths under suction. The small vertical velocity is applied by

9 means of a "ramp" in which the boundary condition is increased linearly from zero to

10 the desired value to preserve quasi-static conditions. For this purpose a FISH function

11 ramp is defined for the condition of velocity applied as a ramp from 0.0 to $10^{-8} /$ step

12 over 30,000 steps. It should be mentioned that, in this analysis grid-points at the caisson

13 top are identified by a FISH function to recognise the top nodes of the soil plug.

14 Applying velocity using "ramp" is especially effective approach for this kind of

15 problems because of the big contrast in stiffness between steel and soil, which produces

16 a large difference in natural periods of this model (Itasca, 2009). In this study, the

17 suction installation process is simulated for different values of scaled embedment depth

$18 \mathrm{~h}^{*}=0.2,0.4,0.6,0.8$ and 1 and to do this a coupled flow-mechanical interaction

19 analysis is used to model the whole suction installation process. Since, this study is

20 primarily devoted to the analysis of suction response for different caisson geometries

21 and wall thicknesses, the initial penetration process of the caisson which normally

22 occurs under self-weight is outside the scope of this paper. 


\section{6. Effect of pore water seepage on soil resistance to caisson penetration}

2 Water seepage caused by suction produces a hydraulic gradient which on both faces of

3 the caisson wall varies with depth. When suction is applied, the pressure gradient inside

4 the caisson cavity has positive values, which indicates upward water flow and its

5 magnitude is higher than outside the caisson where seepage flow is downward. In

6 addition, the upward seepage force created inside the caisson cavity due to suction is

7 larger than the downward seepage force that occurs outside, and this causes more

8 reduction in effective stress inside the caisson than increase in the same stress on the

9 outer side. Generally this results into an overall reduction in the lateral effective stress

10 on the caisson wall and as a consequence, the frictional soil resistance to caisson

11 penetration is reduced (Harireche et al., 2013).

12 Figure 4 illustrates how frictional and tip resistances vary during suction installation at

13 different normalised depths $\mathrm{h}^{*}$. The results have been presented as a normalised

14 resistance force $\left(\mathrm{F} / \gamma^{\prime} \mathrm{D} 3\right)$ against normalised embedment $\left(\mathrm{h}^{*}=\mathrm{h} / \mathrm{D}\right)$ depth. It can be

15 seen that soil shear and tip resistances increase with an increasing penetration depth.

16 However, the magnitude of the normal force at the caisson tip is considerably less than

17 the shear forces around the caisson wall which indicates a minor effect of tip resistance

18 compare with shear resistances around the caisson wall during suction installation

19 process. 


\section{Figure 4}

\section{7. Required Suction for different caisson geometries}

2 The required suction to install different caisson models (Table 1) has been illustrated in

3 Figure 5. These results have been presented as a normalised pressure $\left(p / \gamma^{\prime} D\right)$ versus

4 normalised penetration $\left(h^{*}=h / D\right)$, where $p$ is the excess pore-water pressure that

5 indicates the required amount of suction during the installation and $\gamma^{\prime}$ is the submerged

6 unit weight of the soil. Presenting the results in a normalised form is advantageous

7 because they can be used for any size of caisson foundation.

\section{Figure 5}

8 It is clear from Figure 5 that suction curves follow a similar trend regardless of caisson

9 geometry and wall thickness. The normalised suction pressure appears to increase in a

10 relatively non-linear way with the normalised embedment depth in all cases.

\section{8. Effect of wall thickness and absolute caisson size on soil resistance}

12 The results of caisson installation with different wall thicknesses are shown in Figure 6.

13 This figure indicates the installation behaviour of two caisson types, namely: $12 \mathrm{~m}$ in

14 diameter, $\mathrm{t} / \mathrm{D}=0.5 \%$ and same size but with a thicker wall, $\mathrm{t} / \mathrm{D}=1 \%$. Figure 6 shows

15 that the required amount of suction pressure for a thicker caisson is higher: this 
1 phenomenon emphasises the effect of tip resistance during the caisson installation

2 process even if it remains small compared to shear resistance. Figure 6 shows clearly

3 how wall thickness affects tip resistance. Obviously, such a component of soil resistance

4 to caisson penetration is also affected by suction induced seepage.

\section{Figure 6}

5 In order to investigate the effect of absolute caisson size two different caisson diameters

6 with similar wall thickness ratio $(\mathrm{t} / \mathrm{D}=1 \%)$ are investigated and the results are

7 presented in Figure 7. these results show that the normalised suction pressure in both

8 cases is very similar, which is a consequence of the normalisation procedure. Obviously,

9 this result confirms that for larger caisson size the absolute amount of suction pressure

10 (without normalisation) during installation is higher, and this is consistent with the study

11 conducted by Tran et al. (2004).

\section{Figure 7}




\section{9. Comparisons with centrifuge tests}

2 In this section centrifuge tests conducted by Tran \& Randolph, (2008) are studied and

3 compared to the FLAC3D simulations performed in this study. The centrifuge tests were

4 conducted in saturated sand with a negligible amount of fines. In each test the caisson

5 was completely submerged before touching the seabed surface. Caisson installation into

6 the seabed was performed in the same way as in the field. The installation procedure

7 consists of two stages: a self-weight installation phase followed by a suction installation

8 stage. Table 3 shows the dimensions of the model caissons subjected to the centrifuge

$9 \quad$ tests conducted by Tran \& Randolph (2008).

$\underline{\text { Table } 3}$

10 Since this study is focused on the suction installation process, only centrifuge test data

11 related to the suction installation phase is considered. In the following diagram $\mathrm{L}_{\text {suction }}$

12 represents the caisson penetration due to the applied suction.

\section{Figure 8}

13 It can be seen from Figure 8 that for the caisson with similar diameter and wall

14 thickness in both centrifuge and FLAC3D models (centrifuge test II and Caisson model

15 II), the normalised suction is predicted with a good agreement between the two

16 procedures. This confirms the accuracy of the explicit method. 
1 Since the effect of absolute caisson size on normalised suction pressure is not

2 considerable (Figure 7) the results of centrifuge test I with diameter 10m are compared

3 with the caisson model I and presented in Figure 9.

\section{Figure 9}

4 It appears from Figure 9 that for a smaller aspect ratio $t / D=0.5 \%$, the suction pressure

5 predicted by FLAC3D is less than the value measured in centrifuge tests. It is important

6 to note that Tran \& Randolph, 2008, observed differences of similar order when they

7 compared their centrifuge test results with field trials. They reported that such a

8 difference may be attributed to the discrepancy between cone resistance measured in the

9 centrifuge test and the actual tip resistance in the field test performed on the caisson

10 with a thinner wall thickness $(\mathrm{t} / \mathrm{D}=0.5 \%)$.

\section{10. Conclusions}

13 The effects of suction pressure on soil resistance have been considered for different

14 caisson geometries and wall thicknesses for caisson installation in sand. A series of

15 numerical simulations using FLAC3D were developed to predict the required amount of

16 suction pressure during the installation process for various embedment depths. The most

17 significant observation which was also obtained by centrifuge testing (Tran \&

18 Randolph, 2008) is that the suction pressure will rise continuously with wall embedment

19 depth during suction caisson installation. The results obtained by FLAC3D regarding 
1 suction at different stages of the penetration depth have been compared with

2 experimental data and a good agreement was observed, especially for larger caisson

3 wall thicknesses $(\mathrm{t} / \mathrm{D}=1 \%)$. These results reveal that the explicit approach used provides

4 an insight on how soil resistance evolves under suction during the whole installation

5 process. The outcomes of this study are very helpful in predicting the required amount

6 of suction to penetrate thick wall caissons ( $\mathrm{t} / \mathrm{D}=1 \%$ ) into homogenous sand. On the

7 other hand, it should be mentioned that centrifuge test I has been conducted for a

8 limited penetration depth $\left(\mathrm{L}_{\text {suction }} / \mathrm{D}<0.6\right)$, and in order to provide precise validation of

9 the proposed numerical model for $\mathrm{t} / \mathrm{D}=0.5 \%$ further centrifuge tests are required to

10 cover larger suction penetration depths, i.e. $\mathrm{L}_{\text {suction }} / \mathrm{D}>0.6$.

\section{Acknowledgement}

12 Funding of a $\mathrm{PhD}$ scholarship by the University of Greenwich to support the first author

13 is gratefully acknowledged.

\section{References:}

Achmus, M., Akdag, C.T., Thieken, K., 2013, Load-bearing behaviour of suction bucket foundations in sand, Applied Ocean Research, 43, 157-165.

Bransby, M. F. \& Yun, G. J. 2009. The undrained capacity of skirted strip foundations under combined loading. Geotechnique, 59, No. 2, 115-125.

Bye, A., Erbrich, C. T., Rognlien, B. \& Tjelta, T. I., 1995. Geotechnical design of bucket foundations. Houston, Texas, Proceedings of Offshore Technology Conference (OTC), p. $16 \mathrm{pp}$.

Byrne, B. W., Houlsby, G. T., Martin, C. \& Fish, P., 2002. Suction caisson foundations for offshore wind turbines. Wind Enineering, 26(3), pp. 145-155.

Byrne, B. W. \& Houlsby, G. T., 2003. Foundation for Offshore Wind Turbines. Royal Society, pp. 2909-2930.

Cotter, O., 2006. The installation of suction caisson foundations for offshore renewable energy strctures, Oxford: PhD Thesis, University of Oxford. 
Erbrich, C. t. \& Tjelta, T. I., 1999. Installation of bucket foundations and suction caissons in sand: geotechnical performance. Houston, Proceedings of Offshore Technology Conference (OTC), p. 11pp.

Harireche, O., Mehravar, M. \& Alani, A. M., 2013. Suction caisson in stallation in sand with isotropic permeability varying with depth. Applied Ocean Research, Volume 43, pp. 256-263.

Harireche, O., Mehravar, M. \& Alani, A. M., 2014. soil conditions and bounds to suction during the installation of caisson foundations in sand. Ocean Engineering, pp. 164-173.

Hogervorst, J. R., 1980. Field trials with large diameter suction piles. Houston, Texas, Proceedings of the Offshore Technology Conference (OTC).

Houlsby, G. T. \& Byrne, B. W., 2005. Design procedures for installation of suction caissons in sand. Proceedings of the Institution of Civil Engineers (ICE), Geotechnical Engineering, pp. 135-144.

Houlsby, G. T. \& Byrne, B. W., 2000. Suction caisson foundations for offshore wind turbines and anemometer. Wind Engineering, 24(4), pp. 249-255.

Ibsen, L.B. \& Thilsted, C.L., 2010. Numerical study of piping limits for installation of large diameter buckets in layered sand. Proceedings of the seventh European conference on numerical methods in geotechnical engineeering, Trondheim, Norway, Thomas Benz \& Steinar Nordal (eds). London: C R C Press LLC, pp. 921-926.

Ibsen, L.B. \& Thilsted, C.L., 2011. Numerical study of piping limits for suction installation of offshore skirted foundations and anchors in layered sand. Frontiers in Offshore Geotechnics II - Gouvernec \& White (eds). Taylor \& Francis Group, London, ISBN 978-0-415-58480-7

Ibsen, L. B., Barari, K. A. \& Larsen, K. A., 2014. An adaptive plasticity model for bucket foundations. Journal of Engineering Mechanics, ASCE, 140(2), pp. 361-373.

Ibsen, L. B., Larsen, K. A. \& Barari, A., 2014. Calibration of failure criteria for bucket foundations under general loading. Journal of Geotechnical and Geoenvironmental Engineering, ASCE.

Itasca, 2009. FLAC3D_Fast Lagrangian analysis of continua in 3 Dimensions.

Lacasse, S., 1999. Geotechnical Contributions to offshore development. Houston, Texas, $9^{\text {th }}$ OTRC Honors Lecture: Geotechnical Contributions to Offshore Development.

Mehravar, M., Harireche, O. \& Alani, A. M., 2014. Modelling suction caisson installation in sand using FLAC3D. Delft, Proceeding of 7th European Conference on Numerical Methods in Geotechnical Engineering (NUMGE 2014).

Senders, M. \& Randolph, M. F., 2009. CPT-Based method for the installation of suction caissons in sand. Journal of Geotechnical and Geoenvironmental Engineering, pp. 1425 . 
Senper, D. \& Auvergne, G. A., 1982. Suction anchor piles- a proven alternative to driving or drilling. Houston, Texas, Proceedings of Offshore Technology Conference (OTC).

Tjelta, T. I., 1994. Geotechnical aspect of bucket foundations replacing piles for the Eurpipe16/11-E jacket. Houston, Texas, Proceedings of Offshore Technology Conference (OTC).

Tjelta, T. I., 1995. Geotechnical experience from the installation of the Europipe jacket with bucket foundations. Houston, Texas, Proceedings of Offshore Technology Conference, $p$. 12pp.

Tjelta, T. I., Guttormsen, T. R. \& Hermstad, J., 1986. Large-sclae penetration test at a deepwatersite. Houston, Texas, Proceedings of Offshore Technology Conference (OTC), p. $12 p p$.

Tran, M. N. \& Randolph, M. F., 2008. Variation of suction pressure during caisson installation in sand. Geotechnique, pp. 1-11.

Tran, M. N., Randolph, M. F. \& Airey, D. W., 2004. Exprimental study of suction installation of caissons in dense sand. Vancouver, Canada, OMAE04-51076.

Tran, M. N., Randolph, M. F. \& Airey, D. W., 2005. Study of Seepage Flow and Sand Plug Loosening in Installation of Suction Caissons in Sand. Seoul, South Korea, pp. 516-521.

Tran, M. N., Randolph, M. F. \& Airey, D. W., 2007. Installation of suction caissons in sand with silt layers. Journal of Geotechnical and Geoenvironmental Engineering, 133(10), pp. 1183-1191.

Zhang, S., Zheng, Q. \& Liu, X., 2004. Finite lement analysis of suction penetration seepage field of bucket foundation platform with application to offshore oilfield development. Ocean Engineering, pp. 1591-1599. 


\section{$\underline{\text { Table Captions }}$}

Table 1.

Dimensions of caisson model

Table 1.

Soil properties for model tests

Table 3.

Geometry of centrifuge tests 
Table 1: Dimensions of caisson model

\begin{tabular}{|c|c|c|c|}
\hline Caisson model & $\begin{array}{c}\text { Model size }(\mathrm{m}) \\
\mathrm{D} \times \mathrm{t}\end{array}$ & $\mathrm{h}_{\max } / \mathrm{D}$ & $\mathrm{t} / \mathrm{D}:(\%)$ \\
\hline I & $12 \times 0.06$ & 1 & 0.5 \\
\hline II & $6 \times 0.06$ & 1 & 1 \\
\hline III & $12 \times 0.12$ & 1 & 1 \\
\hline
\end{tabular}

Table 2: Soil properties for model tests

\begin{tabular}{|c|c|c|c|c|c|c|c|c|}
\hline & $\begin{array}{c}\text { Dry } \\
\text { density } \\
\left(\mathbf{k g} / \mathbf{m}^{\mathbf{3}}\right)\end{array}$ & $\begin{array}{c}\text { Wet } \\
\text { density } \\
\left(\mathbf{k g} / \mathbf{m}^{\mathbf{3}}\right)\end{array}$ & $\begin{array}{c}\text { Young's } \\
\text { modulus } \\
(\mathbf{M P a})\end{array}$ & $\begin{array}{c}\text { Poisson's } \\
\text { ratio }\end{array}$ & $\begin{array}{c}\text { Bulk } \\
\text { modulus } \\
(\mathbf{M P a})\end{array}$ & $\begin{array}{c}\text { Shear } \\
\text { modulus } \\
(\mathbf{M P a})\end{array}$ & $\begin{array}{c}\text { Internal } \\
\text { friction } \\
\text { angle }\end{array}$ & $\begin{array}{c}\text { Cohesion } \\
(\mathbf{M P a})\end{array}$ \\
\hline $\begin{array}{c}\text { Soil } \\
\text { (Sand) }\end{array}$ & 1230 & 1550 & 100 & 0.3 & 83.33 & 38.46 & 35 & 0 \\
\hline
\end{tabular}

Table 3: Geometry of centrifuge tests

\begin{tabular}{|c|c|c|}
\hline Centrifuge test & $\begin{array}{c}\text { Model caisson size }(\mathrm{m}) \\
\mathrm{D} \times \mathrm{t}\end{array}$ & $\mathrm{t} / \mathrm{D}(\mathrm{\%})$ \\
\hline $\mathrm{I}$ & $10 \times 0.05$ & 0.5 \\
\hline II & $6 \times 0.06$ & 1 \\
\hline
\end{tabular}




\section{Figure Captions}

\section{Figure 1}

Model geometry and finite difference mesh

\section{Figure 2}

Normalised geometry and boundary condition

\section{Figure 3}

Finite Difference mesh and interfaces around the caisson wall

\section{Figure 4}

Normalised resistance forces during suction installation in homogenous sand $(\mathrm{t} / \mathrm{D}=0.5 \%)$

\section{Figure 5}

Required suction for different caisson geometries

\section{Figure 6}

Effect of caisson wall thickness ratio t/D on soil resistance

\section{Figure 7}

Effect of absolute caisson size on soil resistance

\section{Figure 8}

Comparison between centrifuge test II and numerical simulation of caisson II ( $\mathrm{t} / \mathrm{D}=1 \%)$

\section{Figure 9}

Comparison between centrifuge test I and numerical simulation of caisson I $(\mathrm{t} / \mathrm{D}=0.5 \%)$ 


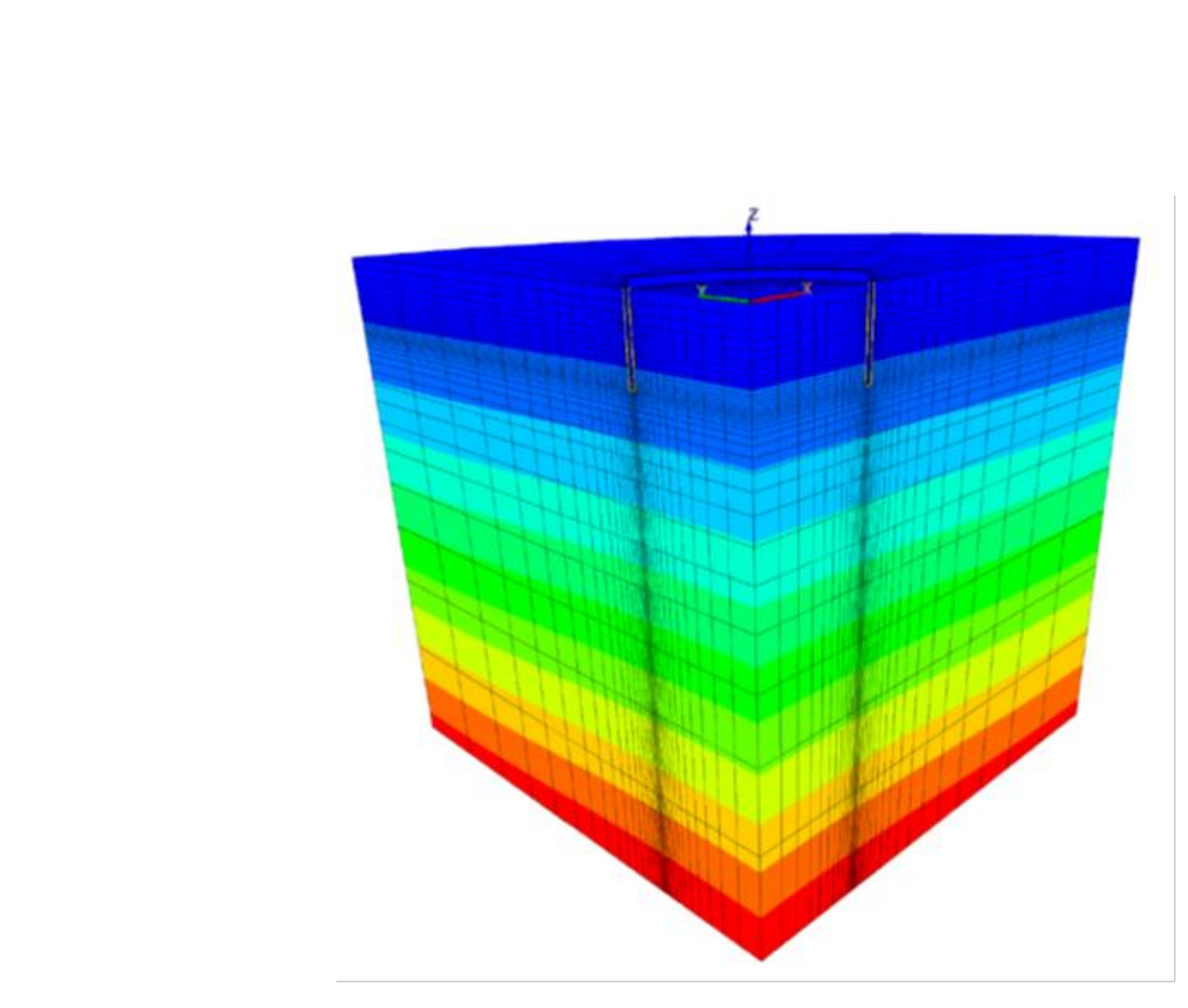

Figure 1.
our on the Web)

Figure 1.
(Colour on the Web)

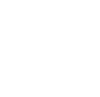

Figure 1.
(Colour on the Web)

(n)
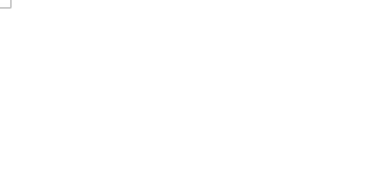


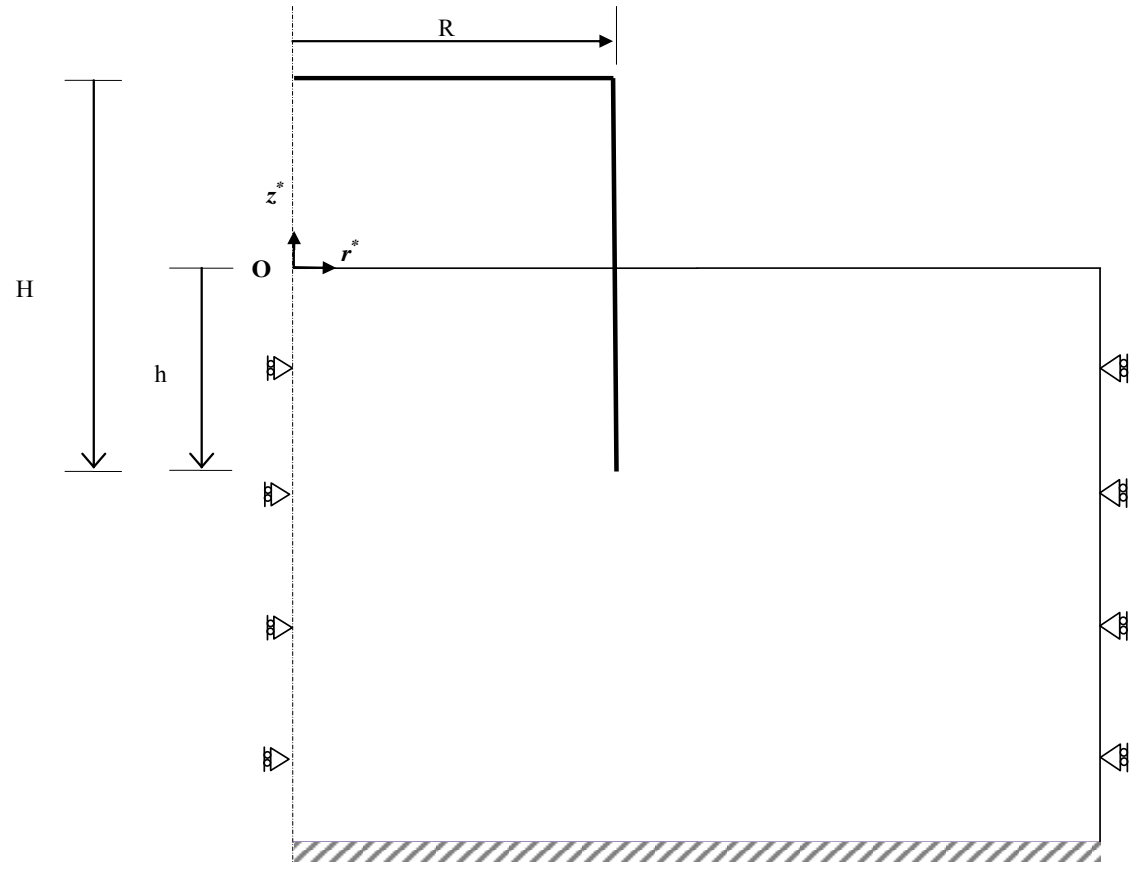

Figure 2.

(Colour on the Web) 


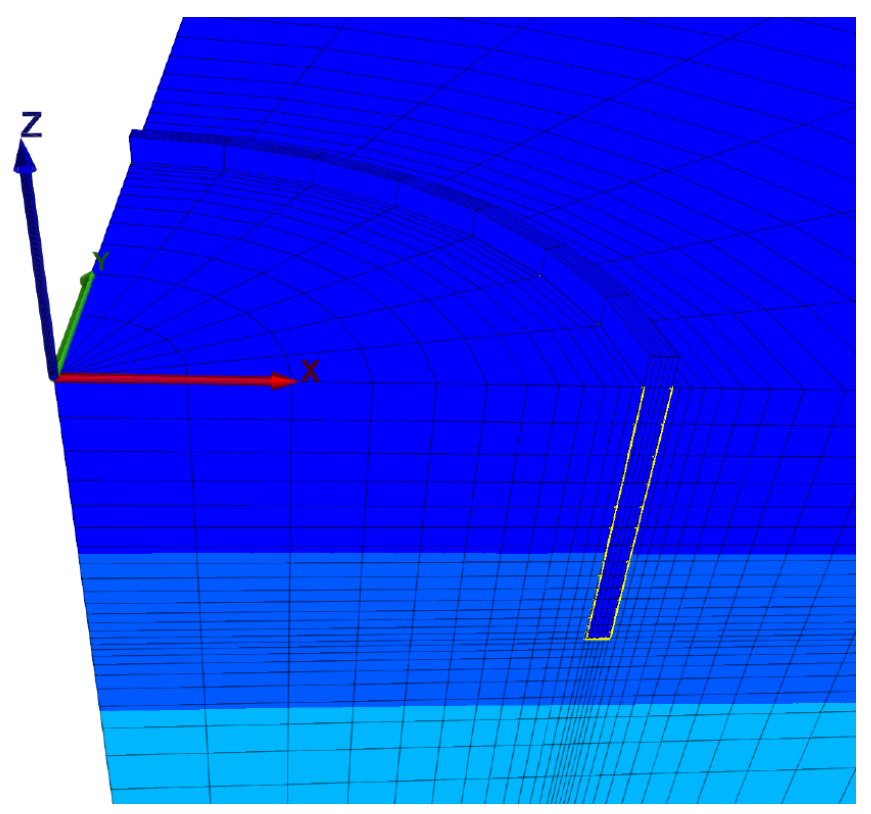

Figure 3.

(Colour on the Web) 


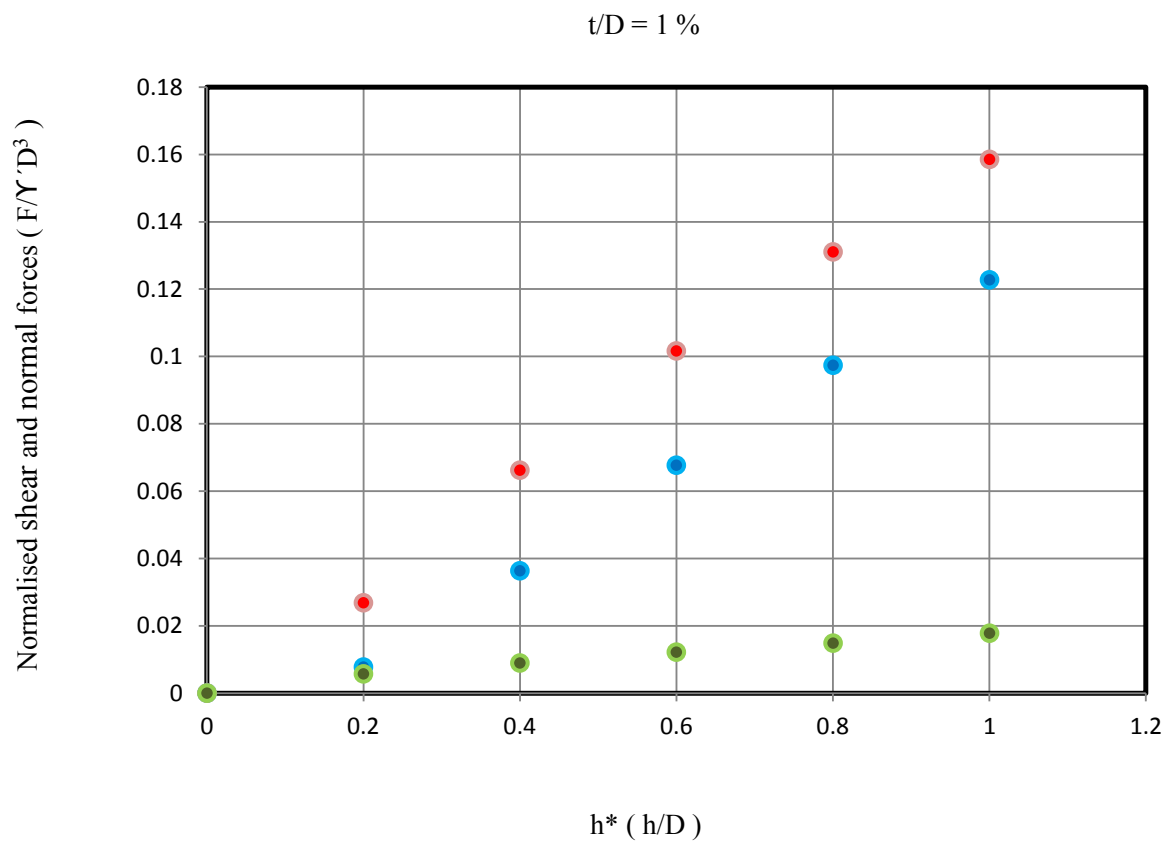

Figure 4.

(Colour on the Web) 


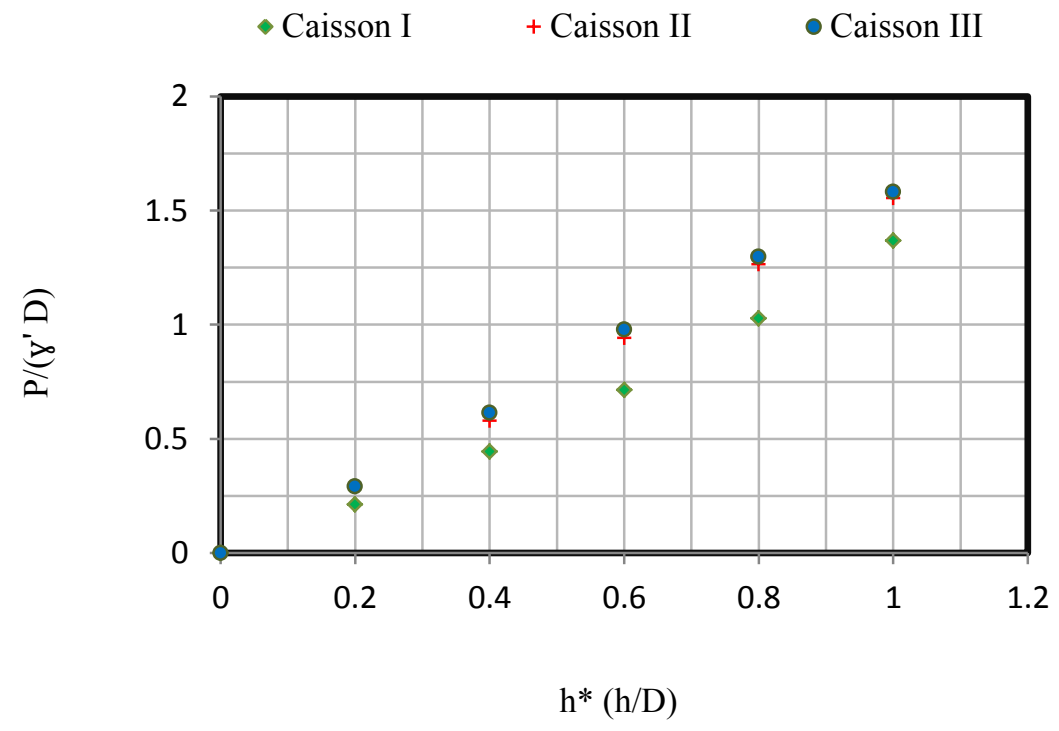

Figure 5.

(Colour on the Web)

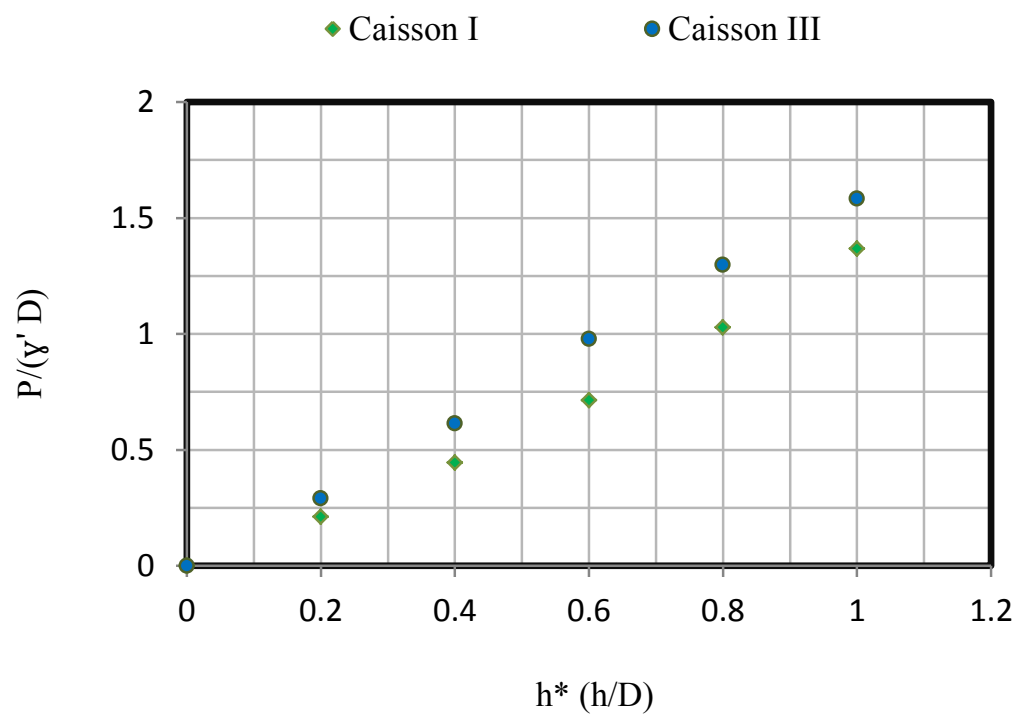

Figure 6.

(Colour on the Web) 


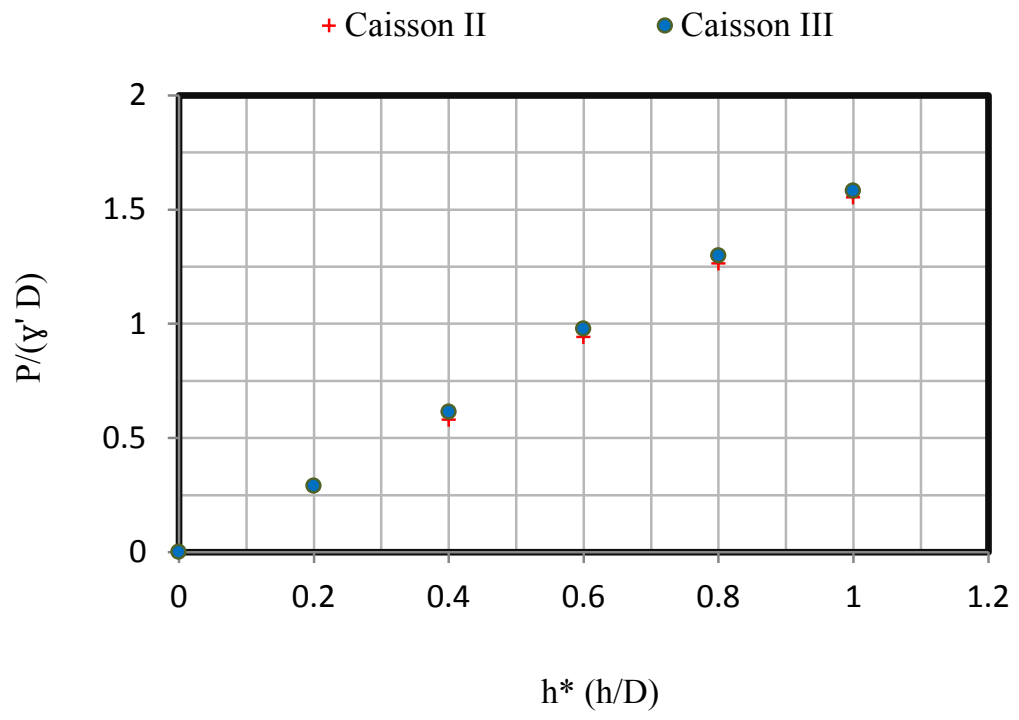

Figure 7.

(Colour on the Web) 


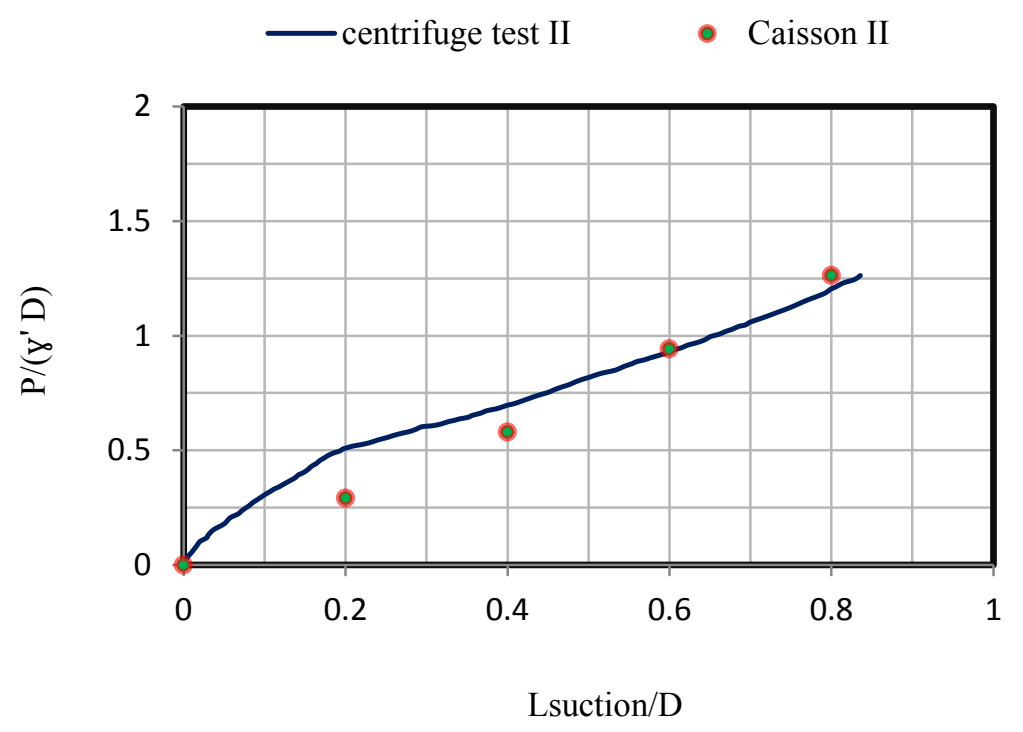

Figure 8.

(Colour on the Web) 


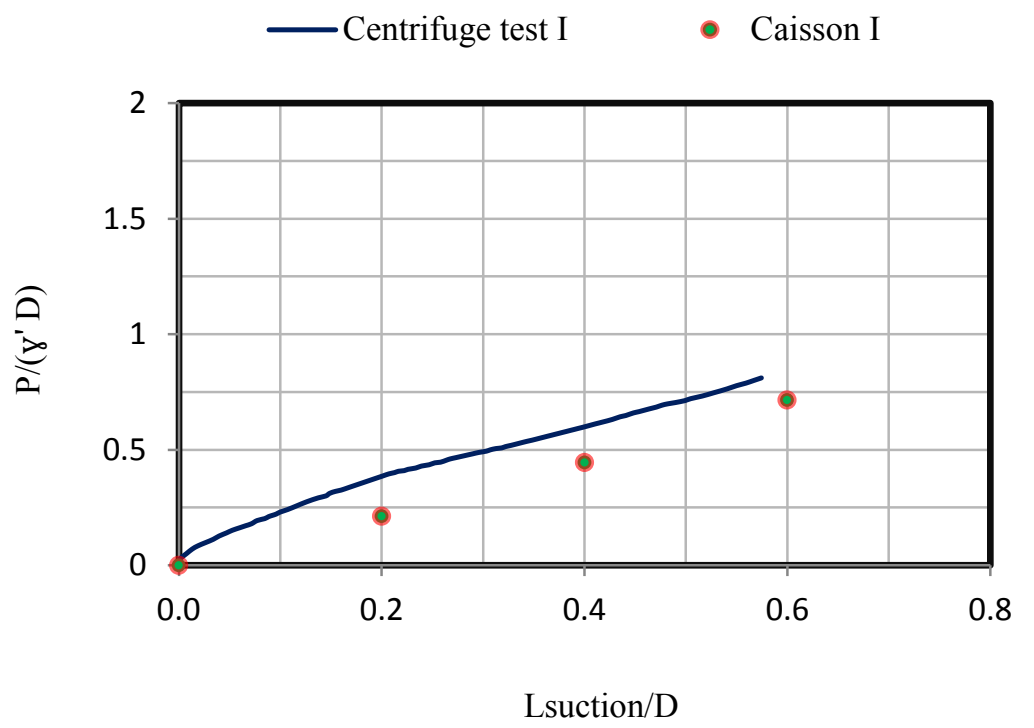

Figure 9.

(Colour on the Web) 